\title{
Tropical moist Polylepis stands at the treeline in East Bolivia: the effect of elevation on stand microclimate, above- and below-ground structure, and regeneration
}

\author{
Dietrich Hertel · Karsten Wesche
}

Received: 24 January 2007/Revised: 10 July 2007 / Accepted: 18 October 2007 / Published online: 29 January 2008

(C) The Author(s) 2008

\begin{abstract}
We studied Polylepis forests along an elevational transect between 3,650 and 4,050 $\mathrm{m}$ a.s.l. at the treeline of the moist eastern cordillera in Bolivia to examine changes in above- and below-ground stand structure, leaf and root morphology, and regeneration in relation to stand microclimate. Field measurements and model predictions indicated relatively cold growth conditions of the Polylepis forests. Tree height, stem diameter, and basal area of the stands decreased markedly while stem density increased with elevation. Leaf morphology differed between the two occurring Polylepis species, and trees at the treeline had smaller leaves with higher specific leaf area. In contrast, fine root biomass increased from $37 \mathrm{~g} \mathrm{~m}^{-2}$ at the lowermost stand to $234 \mathrm{~g} \mathrm{~m}^{-2}$ at the treeline. Trees of the uppermost stand had higher specific root surface area and a much higher number of root tips per unit dry mass. Thus, root surface area and total number of root tips per unit ground area increased conspicuously from the lowermost stand to the treeline. Density of young growth inside the forest increased towards the treeline, while density in the open grassland decreased with elevation. Young growth originated from sexual reproduction at the lower forest but
\end{abstract}

Communicated by M. Buckeridge.

\section{Hertel $(\bowtie)$}

Plant Ecology, Albrecht-von-Haller Institute of Plant Sciences, University of Göttingen, Untere Karspüle 2, 37073 Göttingen, Germany

e-mail: dhertel@gwdg.de

\section{K. Wesche}

Institute of Biology, Geobotany and Botanical Garden,

Martin-Luther University Halle-Wittenberg,

Am Kirchtor 1, 06108 Halle/Saale, Germany was comprised exclusively of root suckers at the treeline stand. We conclude that both the marked change in carbon allocation towards the root system, as well as the changes in root morphology with elevation indicate an adaptation to reduced nutrient supply under cold conditions of these Polylepis stands at the treeline in E Bolivia.

Keywords Fine root biomass - Leaf morphology · Reproduction · Root morphology · Temperature

\section{Introduction}

In tropical and subtropical South America, isolated forest patches covered by trees of the genus Polylepis are present above the closed upper montane forest belt. Among the ca. 30 existing Polylepis species several are found at sites with extreme climatic conditions reaching altitudes up to $5,200 \mathrm{~m}$ a.s.l., and covering a wide range of high to very low rainfall (Simpson 1986; Kessler 1995; Kessler and Schmidt-Lebuhn 2005). There has been a long standing debate whether these forest represent living "fossil" remnants of warmer postglacial periods or remnants of a potentially larger natural forest belt, that was destructed by long-term human land-use (Ellenberg 1979; Goldstein et al. 1994; Kessler 1995; Kessler and Hohnwald 1998; Hensen 2002). However, stands forming at least a potential upper treeline are thus of high interest for treeline ecology.

Many studies on high elevation forest sites documented a decline in above-ground biomass and production at treeline sites compared to forest sites at lower elevation. This is often accompanied by notable changes in leaf morphological and chemical traits. The changes in structure, morphology, and carbon cycle are predominantly influenced by the decrease in temperature with elevation (e.g., 
Tranquillini 1979; Oshawa 1990; Körner 1998). Recent studies confirmed that treelines are on a global scale associated with a mean seasonal root zone temperature of $6.7^{\circ} \mathrm{C}$ (Körner and Paulsen 2004).

Analyses of the mobile carbohydrate contents revealed higher pools at the treeline compared to trees below the treeline, which is seen as indicating carbon sink-limitation rather than carbon source-limitation as the principle factor of tree growth restriction (Hoch et al. 2002; Hoch and Körner 2003; Körner 2003a). Other authors stated that constraints in fruit production, seed dispersal and viability, and seedling establishment are crucial for forest survival and extension at the treeline (Wardle 1981; Cuevas 2000, 2003; Cierjacks et al. 2008). However, detailed studies on Polylepis species growing at high altitudes were rarely conducted so far, and failed to consider the root system of the trees (e.g. Rada et al. 1996; Velez et al. 1998; Rundel et al. 2003; Garcia-Nunez et al. 2004; Renison et al. 2004; Hoch and Körner 2005).

We investigated Polylepis stands along an elevational transect at the treeline of the eastern Andean cordillera in Bolivia. The objective of our study was to test the hypotheses that (1) elevational changes in the aboveground structure of high-Andean Polylepis forests are accompanied by changes in the structure of the root system as well, that (2) the Polylepis trees show significant adaptations in leaf and root morphology to the harsh growth conditions at the treeline, and that (3) regeneration pattern of Polylepis trees changes with increasing elevation.

Hence, the aims of our study were to analyse (1) how above- and below-ground structure of the Polylepis forests changes with elevation, (2) whether Polylepis trees differ in morphological and chemical leaf and root traits along the elevational transect, and (3) if constraints in regeneration of the Polylepis stands may contribute to treeline formation.

\section{Material and methods}

Study site location and species composition of the forests

The study was conducted in the area of Chumbre Chulumani (Department Cochabamba, Province Tiraque) at the humid eastern cordillera of Bolivia between August and September 2003. In this remote area, some largely undisturbed forest stands of Polylepis species grow above a closed montane forest belt. We selected three neighbouring forest stands mainly built by Polylepis trees along an elevational transect between 3,650 and 4,050 $\mathrm{m}$ a.s.l. The lowermost forest was dominated by trees of Polylepis lanata (Kuntze) M. Kessler \& Schmidt-Leb. ${ }^{1}$ and had a lower second tree layer dominated by Oreopanax macrocephalus, Baccharis pentlandi and other tree species; herbaceous plants were less abundant with some ferns and Fuchsia plants. The two forests at higher elevation were dominated by trees of Polylepis pepei B.B. simpson. At $3,800 \mathrm{~m}$ a.s.l. individuals of the genus Gynoxis were admixed in the forest, while in the uppermost stand (at 4,050 m a.s.l.) some Ribes shrubs were present. In both forests, the soil was covered by mosses and herbaceous plants (genera Luzula and Bomarea). Following the definition given by Körner and Paulsen (2004), we assume that the highest forest stand (at 4,050 m a.s.l.) represents the upper treeline in this region (hence, the upper distribution limit of connected forest patches in the area). All forests grow on east-facing slopes with various inclination (Table 1).

\section{Soil characteristics}

All three Polylepis forests were located on boulder slopes with medium to low mineral soil contents. The mineral soil was covered by an organic layer of slightly increasing thickness with elevation (Table 1). Thickness of the mineral soil layer was ca. 8 and $14.5 \mathrm{~cm}$, respectively, in the two lower forest stands, but declined to less than $2 \mathrm{~cm}$ in the uppermost stand. Soil chemical conditions tended to be less favourable in the two uppermost Polylepis stands: mineral and organic soil layers were less acidic at the lowermost site, and cation exchange capacity as well as base saturation were higher at the lowermost site (Table 1). The C:N ratio of the organic layer increased along the elevational transect, although the $\mathrm{C}: \mathrm{N}$ ratio of the mineral soil showed no clear altitudinal gradient. The resinextractable soil phosphorus fraction (as a proxy for plantavailable P), on the other hand, was highest at the treeline site (Table 1).

\section{Climatic measurements}

There are no permanent weather stations in the study region, so we had to use extrapolated values from a standard model (Hijmans et al. 2005) to estimate average climatic conditions. The data are based on lapse rates and have a moderate spatial resolution $\left(1 \mathrm{~km}^{2}\right)$ and thus yield similar values for all three stands. However, microclimatic differences among sites were measured on a short-term base during fieldwork (4 days). Dataloggers

\footnotetext{
$\overline{1}$ Taxonomy of the Polylepis species according to Kessler and Schmidt-Lebuhn (2005).
} 
Table 1 Topographical and soil chemical characteristics of the three Polylepis stands
Given are means and standard errors for the soil parameters; $n=20$ for soil layer thickness, and $n=5$ for $\mathrm{pH}, \mathrm{C} / \mathrm{N}$, extractable phosphorus $\left(\mathrm{P}_{\text {resin }}\right)$, cation exchange capacity CEC, and base saturation. For $\mathrm{pH}$, minimum and maximum values are presented in brackets

\begin{tabular}{|c|c|c|c|c|}
\hline & & Plot A & Plot B & Plot C \\
\hline \multicolumn{2}{|l|}{ Elevation (m a.s.1.) } & 3,650 & 3,800 & 4,050 \\
\hline \multirow{2}{*}{\multicolumn{2}{|c|}{ Coordinates }} & $17^{\circ} 16^{\prime} 36.6^{\prime \prime} \mathrm{S}$ & $17^{\circ} 16^{\prime} 23.6^{\prime \prime} \mathrm{S}$ & $17^{\circ} 16^{\prime} 18.5^{\prime \prime} \mathrm{S}$ \\
\hline & & $65^{\circ} 43^{\prime} 09.8^{\prime \prime} \mathrm{W}$ & $65^{\circ} 43^{\prime} 27.1^{\prime \prime} \mathrm{W}$ & $65^{\circ} 43^{\prime} 54.6^{\prime \prime} \mathrm{W}$ \\
\hline \multicolumn{2}{|l|}{ Exposition } & $\mathrm{NE}$ & $\mathrm{E}$ & SE \\
\hline \multicolumn{2}{|l|}{ Inclination $\left(^{\circ}\right)$} & 4 & 22 & 32 \\
\hline \multirow{2}{*}{$\begin{array}{l}\text { Mean thickness soil } \\
\text { layers }(\mathrm{cm})\end{array}$} & Organic layer & $9.8 \pm 2.1$ & $11.2 \pm 1.8$ & $13.1 \pm 1.5$ \\
\hline & Mineral soil & $8.2 \pm 1.7$ & $14.5 \pm 2.1$ & $1.7 \pm 0.4$ \\
\hline \multirow[t]{2}{*}{$\mathrm{pH}\left(\mathrm{H}_{2} \mathrm{O}\right)$} & Organic layer & $6.1(5.8-6.3)$ & $4.7(4.6-5.0)$ & $4.8(4.7-5.3)$ \\
\hline & Mineral soil & $6.0(5.8-6.2)$ & $4.4(4.1-4.6)$ & $4.2(4.2-4.4)$ \\
\hline \multirow[t]{2}{*}{$\mathrm{C} / \mathrm{N}\left(\mathrm{mol} \mathrm{mol}^{-1}\right)$} & Organic layer & $20.2 \pm 0.6$ & $25.4 \pm 0.6$ & $37.6 \pm 3.1$ \\
\hline & Mineral soil & $16.1 \pm 0.7$ & $14.8 \pm 0.2$ & $17.9 \pm 0.3$ \\
\hline \multirow[t]{2}{*}{$\mathrm{P}_{\text {resin }}\left(\mu \mathrm{mol} \mathrm{P} \mathrm{g}^{-1}\right)$} & Organic layer & $6.6 \pm 0.5$ & $7.1 \pm 1.5$ & $14.2 \pm 2.6$ \\
\hline & Mineral soil & $3.7 \pm 1.1$ & $1.2 \pm 0.1$ & $5.6 \pm 0.6$ \\
\hline \multirow[t]{2}{*}{$\mathrm{CEC}\left(\mu \mathrm{mol}_{\mathrm{c}} \mathrm{g}^{-1}\right)$} & Organic layer & $936 \pm 32$ & $740 \pm 76$ & $609 \pm 55$ \\
\hline & Mineral soil & $723 \pm 49$ & $259 \pm 12$ & $496 \pm 59$ \\
\hline \multirow[t]{2}{*}{ Base saturation $(\%)$} & Organic layer & $96.2 \pm 0.5$ & $45.9 \pm 3.9$ & $54.0 \pm 3.3$ \\
\hline & Mineral soil & $96.3 \pm 1.1$ & $9.3 \pm 1.2$ & $25.8 \pm 2.4$ \\
\hline
\end{tabular}

(BauFeuchteLog, Driesen \& Kern, Germany) were placed inside the forests and in the open grassland east of the forest stands at the same elevation and exposition; sensors were screened against direct radiation with ventilated plastic containers. Data were recorded for two levels above the ground $(+20$ and $+200 \mathrm{~cm})$ and at -10 and $-20 \mathrm{~cm}$ soil depth. Recording intervals were 2 min, but only mean values and maximum and minimum ranges are reported here.

\section{Above-ground forest structure}

We recorded tree height, diameter at breast height (dbh) of all tree stems, and stem density in plots of $50 \mathrm{~m}^{2}$ at the uppermost site, while plot size was 100 and $300 \mathrm{~m}^{2}$ in the mid-positioned and the lowermost site, respectively, to include a sufficient number of dominant tree individuals per plot. Tree height was measured using a Hagloef (Sweden) Vertex III Ultrasonic device from 12 randomly selected tree individuals in the two uppermost stands, and from 15 trees in the lowermost stand covering the two crown strata in this forest. The stem density and dbh data were used to calculate the stand basal area of the forest plots.

\section{Leaf morphology and chemistry}

Ten leaves from different branchlets were sampled from the upper sun-lit crown of six Polylepis trees, each stand, resulting in a total of 60 leaves per stand. Leaves were stored in paper bags, air dried, and transported to the Göttingen laboratory within a few days. Leaf area was measured on scanned images of the rehydrated leaves (WinFolia software package, Régent Instruments Inc., Canada). Dry mass of the leaves was determined after drying for $48 \mathrm{~h}$ at $70^{\circ} \mathrm{C}$, and then used to calculate the specific leaf area (SLA). Dried leaves were ground for analyses of leaf chemistry and carbon isotopes. Total $\mathrm{C}$ and $\mathrm{N}$ contents as well as stable carbon isotopic status $\left(\delta^{13} \mathrm{C}\right.$ values) were measured by stable-isotopic mass spectrometry. Total P concentration was determined photometrically with a staining procedure (p-yellow), after digestion of leaf tissue with $65 \% \mathrm{HNO}_{3}$ at $195^{\circ} \mathrm{C}$.

Structure of the fine root system

Root samples were taken with a soil corer $(3.5 \mathrm{~cm}$ in diameter) from the organic layer and the upper mineral soil (0-10 and 10-20 cm, respectively) at 20 randomly selected sampling locations per study plot. As described above, mean thickness of the mineral soil was only about $8 \mathrm{~cm}$ in the lowermost stand and less than $2 \mathrm{~cm}$ in the uppermost stand; hence, only in the mid-positioned stand a notable number of samples reached mineral soil depths below $10 \mathrm{~cm}$. The soil samples were transferred to plastic bags and stored at ca. $4^{\circ} \mathrm{C}$. The samples were transported to the laboratory at the University of Göttingen within a few days, where processing of the samples took place within 60 days. In the lab, the samples were soaked in water and cleaned 
from soil residues using a sieve with a mesh size of $0.25 \mathrm{~mm}$. Large root fractions ( $>10 \mathrm{~mm}$ in length) were extracted by hand with tweezers. Only fine roots of trees (roots $<2 \mathrm{~mm}$ in diameter) were considered for the analysis. Live (biomass) and dead rootlets (necromass) were distinguished under the stereomicroscope by color, root elasticity, and the degree of cohesion of cortex, periderm and stele. A dark cortex and stele, or a white, but nonturgid cortex, or the complete loss of the stele and cortex with only the periderm being present, were used as indicators of root death (e.g., Persson 1978; Hertel and Leuschner 2002). This fine root fraction covers the majority of living fine root mass, but represents only a minor part of the fine root necromass, because small fractions ( $<10 \mathrm{~mm}$ length) of dead roots, that may account for a large portion of the whole fine root necromass (Bauhus and Bartsch 1996; Hertel 1999), are hardly recovered. Hence, one third of the samples were subjected to an additional, more detailed analysis of finest root necromass particles ( $<10 \mathrm{~mm}$ in length) applying a method introduced by van Praag et al. (1988) and modified by Hertel (1999). After extraction of the large root fractions the residue of the sample was evenly spread on a large sheet of filter paper $\left(730 \mathrm{~cm}^{2}\right)$ with 36 squares marked on it. Six of the squares were randomly selected and analysed under the stereo-microscope for even the smallest dead fine root fragments. Total mass of small dead rootlets was extrapolated by regression analysis of the ratio of small rootlets to large dead roots ( $>10 \mathrm{~mm}$ in length) recorded in the same sub-sample. Fine root biomass and necromass of each sample were dried at $70^{\circ} \mathrm{C}$ for $48 \mathrm{~h}$ and weighed. The data were expressed in relation to soil volume as fine root mass density (in $\mathrm{g}^{-1}$ ) for the respective soil depths, and as profile fine root mass total $\left(\right.$ in $\mathrm{m}^{-2}$ ).

\section{Root morphology and $\mathrm{C}$ isotopic signature}

One living rootlet per soil sample was analysed for root specific surface area (SRA, in $\mathrm{cm}^{2} \mathrm{~g}^{-1}$ ) using a WhinRhizo (Régent Instruments Inc., Quebec, Canada) visual analysis system with a scanner in the Göttingen lab. Fine root area index (RAI, in $\mathrm{m}^{2}$ root surface area per $\mathrm{m}^{2}$ ground area) was calculated from SRA values and fine root biomass of a respective horizon.

The abundance of live fine root tips was determined by counting all vital tips under the stereo-microscope in the same fine root sample used for analysis of SRA. Tip abundance was expressed on a dry mass basis $\left(\mathrm{n} \mathrm{mg}^{-1}\right)$ or on a stand ground area basis (number of tips per $\mathrm{m}^{2}$ ).

Fine root stable carbon isotopic status $\left(\delta^{13} \mathrm{C}\right.$ values) was measured by stable-isotopic mass spectrometry in the isotopic lab in Göttingen (KOSI).
Polylepis regeneration pattern

The number of juvenile plants $(<2 \mathrm{~cm} \mathrm{dbh})$ was counted on 4 randomly placed subplots of $4 \mathrm{~m}^{2}$ inside the forest stands; these were compared to 4 randomly chosen subplots outside. We excluded shoots emerging directly from bases of established trees. In the two lower forest stands, all seedlings were excavated and checked for obvious connections to adult trees. In the uppermost plot the sheer number of young growth rendered complete assessment impossible so we excavated only a subset (40 shoots).

\section{Statistical analysis}

Climatic data were not replicated, so we refrained from statistical analysis and present condensed raw data instead. All other data sets were analysed for distribution of normality using a Shapiro and Wilk test. Normally distributed data were tested using an ANOVA procedure followed by pair-wise comparison after Scheffé $(\mathrm{p}<0.05)$. Other data sets were tested with one-way Kruskal-Wallis single factor analyses of variance. Significance was determined at $\mathrm{p}<0.05$ in all analyses. If $\mathrm{H}_{\mathrm{o}}$ (no significant difference among the sites or horizons) was rejected, a non-parametric Mann-Whitney two-sample test (U-test) was applied to locate the differences $(\mathrm{p}<0.05)$. All calculations were conducted with the package SAS, version 8.01 (SAS Institute, Cary, NC, USA).

\section{Results}

Microclimate inside and outside the stands

The climate model predicted mean annual temperatures ranging from -0.1 to $15.2^{\circ} \mathrm{C}$ (mean minimum to maximum) with rough mean annual temperature values ranging from 8.5 at the lower to some $6.0^{\circ} \mathrm{C}$ at the middle stand and mean total precipitation of $700-800 \mathrm{~mm}$ (the uppermost stand was not differentiated due to limited spatial resolution). For September, the model predicts a mean daily thermal range between 0.2 and $16.7^{\circ} \mathrm{C}$ at the lower and -2.6 to $14.2^{\circ} \mathrm{C}$ at the uppermost stand. Our own microclimatic measurements at $2 \mathrm{~m}$ above ground (comparable to a standard weather hut) yielded a temperature range between -0.6 and $11.5^{\circ} \mathrm{C}$ at $3,850 \mathrm{~m}$ a.s.l. and between -2.3 and $9.5^{\circ} \mathrm{C}$ at $4,050 \mathrm{~m}$ a.s.l. Measured mean temperatures were low, ranging between $3.4^{\circ} \mathrm{C}$ at $3,680 \mathrm{~m}$ and $1.7^{\circ} \mathrm{C}$ at $4,050 \mathrm{~m}$ (Table 2). This corresponds to a mean

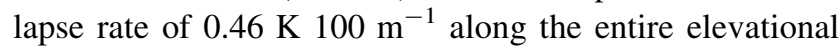
transect. Low lapse rate between the upper two stands 
Table 2 Micro-climatic conditions inside the three Polylepis stands (In) and at the adjacent grasslands (Out)

\begin{tabular}{|c|c|c|c|c|c|c|}
\hline \multirow[t]{2}{*}{ Elevation (m) } & \multicolumn{2}{|l|}{3,650} & \multicolumn{2}{|l|}{3,800} & \multicolumn{2}{|l|}{4,050} \\
\hline & In & Out & In & Out & In & Out \\
\hline $\begin{array}{l}\text { Mean air temperature } \\
\quad+200 \mathrm{~cm}\left({ }^{\circ} \mathrm{C}\right)\end{array}$ & $3.4(1.0-6.3)$ & $3.7(-0.6$ to 11.5$)$ & $2.1(-0.9$ to 4.7$)$ & $1.8(-1.7$ to 6.1$)$ & $1.7(-1.2$ to 6.7$)$ & $1.9(-2.3$ to 9.5$)$ \\
\hline $\begin{array}{l}\text { Mean air temperature } \\
\quad+20 \mathrm{~cm}\left({ }^{\circ} \mathrm{C}\right)\end{array}$ & $3.4(1.5-6.1)$ & n.d. & $1.7(-1.4$ to 4.5$)$ & $1.5(-4.5$ to 8.6$)$ & $1.0(-3.3$ to 7.9$)$ & $2.2(-4.2$ to 17.6$)$ \\
\hline $\begin{array}{l}\text { Mean soil temperature } \\
\quad-20 \mathrm{~cm}\left({ }^{\circ} \mathrm{C}\right)\end{array}$ & $4.3(4.1-4.5)$ & $7.2(6.1-8.6)$ & $2.9(2.7-3.2)$ & $2.7(2.4-3.1)$ & $2.0(1.4-3.7)$ & $2.8(1.4-5.2)$ \\
\hline $\begin{array}{l}\text { Mean VPD +200 } \\
\text { cm (kPa) }\end{array}$ & $0.11(0.03-0.34)$ & $0.15(0.02-0.74)$ & $0.10(0.03-0.31)$ & $0.09(0.02-0.31)$ & $0.13(0.02-0.44)$ & $0.15(0.02-0.66)$ \\
\hline $\begin{array}{l}\text { Mean VPD +20 } \\
\text { cm (kPa) }\end{array}$ & $0.08(0.04-0.23)$ & n.d. & $0.07(0.03-0.19)$ & $0.08(0.02-0.37)$ & $0.11(0.03-0.46)$ & $0.19(0.03-1.40)$ \\
\hline
\end{tabular}

Given are mean temperature and daily mean minimum and maximum values for air temperature and vapor pressure deficit (VPD) at 200 and $20 \mathrm{~cm}$ above ground, and soil temperature at $20 \mathrm{~cm}$ soil depth

suggests that air masses were not homogenous over that altitudinal range.

Conditions were warmer outside the forests, but mean temperatures did not differ much between +200 and $+20 \mathrm{~cm}$ above ground. The range of minimum and maximum temperatures was generally larger near the ground and in the open grassland (Table 2). Both the overall highest and lowest temperatures along the transect were measured in the open grassland at 4,050 $\mathrm{m}$ a.s.l. Temperatures in the soil $(-20 \mathrm{~cm})$ were higher than in the air and this was particularly pronounced in the open grassland (Table 2). Forest soils were found to be cooler than grassland soils at the lowermost and uppermost elevation. Soil temperature in $-10 \mathrm{~cm}$ (data not shown) had higher maximum and lower minimum values than in $-20 \mathrm{~cm}$, but mean temperatures in the two soil depths were almost identical with values inside the forests ranging from 4.3 to $2.0^{\circ} \mathrm{C}$ at 3,680 and 4,050 $\mathrm{m}$ a.s.l., respectively.

Mean vapor pressure deficits (VPD) were generally low at $<0.2 \mathrm{kPa}$ (Table 2). VPD tended to be higher outside the forests, and tended to increase with altitude, with highest values recorded at the uppermost grasslands. There was pronounced diurnal variation, extreme values ranged between 0 and $1.4 \mathrm{kPa}$.

\section{Above-ground structure}

The mean tree height of the stands decreased significantly with elevation from ca. $15 \mathrm{~m}$ at $3,650 \mathrm{~m}$ a.s.l. to some $3 \mathrm{~m}$ at the treeline (Fig. 1 a). This trend was even more pronounced if only Polylepis trees were considered: P. lanata formed an upper tree layer reaching a height of 30 or 32 meters, while the second stratum $(10 \mathrm{~m}$ height $)$ was mainly built up by Oreopanax macrocephalus.

Mean diameter at breast height (dbh) also decreased significantly with elevation (Fig. 1 b). In correspondence to tree height, single individuals of $P$. lanata at $3,650 \mathrm{~m}$ a.s.l. showed dbh values of e.g. 112 or $152 \mathrm{~cm}$, while dbh values at the treeline ranged between 3 and $23 \mathrm{~cm}$.

Stem density increased linearly with elevation by a factor of six (Table 3). Due to the non-linear decrease in stem diameter with elevation, total basal area decreased from $176 \mathrm{~m}^{2} \mathrm{ha}^{-1}$ in the lowermost stand to ca. $67 \mathrm{~m}^{2} \mathrm{ha}^{-1}$ at the treeline (Table 3).

\section{Leaf morphological and chemical status}

The mean leaf area of Polylepis trees at the lowermost site was markedly larger than at the two uppermost stands, but this seemed to be a result of the difference between the two Polylepis species rather than an elevational effect. However, there was a tendency of decreasing leaf areas in $P$. pepei with elevation (Table 4). This is confirmed by a significant reduction in specific leaf area from the middle stand towards the treeline, while $P$. lanata trees at the lowermost site had a much lower specific leaf area compared to P. pepei (Table 4).

Leaf nitrogen concentrations (on a dry matter basis) increased significantly with elevation irrespective of the different species. Expressed on a leaf area unit, $P$. lanata at the lowermost site showed the highest $\mathrm{N}$ content, while $P$. pepei leaves at the treeline site had significantly higher $\mathrm{N}$ contents per unit leaf area compared to the intermediate site (Table 4). Leaf phosphorus concentration was significantly higher in $P$. lanata compared to $P$. pepei based on a dry matter unit as well as on a leaf area unit (Table 4). Leaf phosphorus concentration of $P$. pepei also tended to increase with elevation, but differences were not significant (Table 4).

Analyses of the carbon isotopic status of the leaves indicated no marked differences among stands: the $\delta^{13} \mathrm{C}$ values in $P$. pepei were not significantly different between 

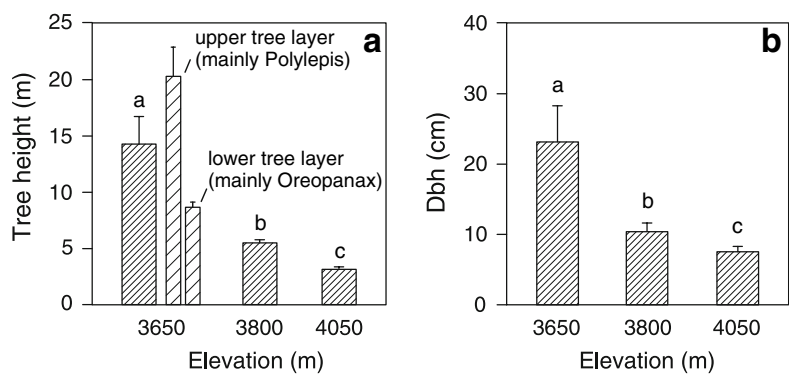

Fig. 1 Tree height and diameter at breast height (dbh) of the three Polylepis stands. Given are means $\pm 1 \mathrm{SE} ; n=12$ for mean tree height and $n=61,75$, and 62 for dbh values at 3,650;3,800; and $4,050 \mathrm{~m}$ a.s.1., respectively. Different letters indicate significant differences between the forests. In the case of the lowermost stand the narrow bars beside indicate tree height means of the two occurring canopy strata

Table 3 Stem density and basal area of the three Polylepis forests

\begin{tabular}{llll}
\hline Elevation $(\mathrm{m})$ & 3,650 & 3,800 & 4,050 \\
\hline Stem density $\left(\mathrm{n} \mathrm{ha}^{-1}\right)$ & 2,033 & 7,500 & 12,400 \\
Basal area $\left(\mathrm{m}^{2} \mathrm{ha}^{-1}\right)$ & 176.0 & 86.3 & 67.3 \\
\hline
\end{tabular}

the two uppermost stands. P. lanata showed a somewhat higher (less negative) value compared to $P$. pepei (Table 4).

Below-ground structure and fine root morphology

The total mass of living fine roots (fine root biomass) of the stands increased significantly with elevation: the middle and the uppermost stand exceeded the fine root biomass of the lowermost stand by factors of 4.9 and 6.3 , respectively (Fig. 2 a). This was due to a significant altitudinal increase in fine root density (biomass per soil volume) in both the organic layer and the upper mineral soil $(0-10 \mathrm{~cm}$; Table 5). The density of fine root necromass (dead fine
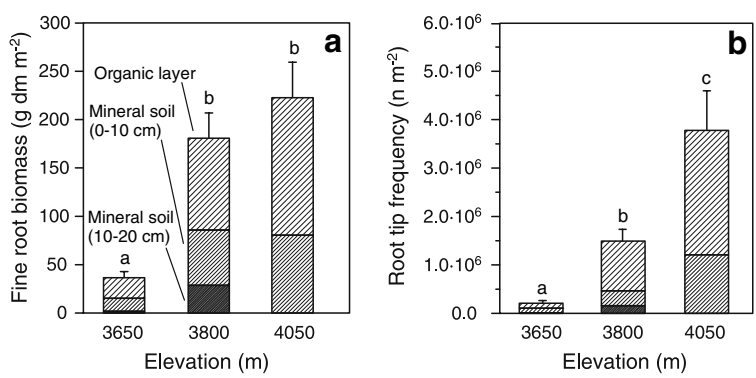

Fig. 2 Fine root biomass and root tip frequency of the Polylepis stands. Given are means $\pm 1 \mathrm{SE} ; n=20$. Different letters indicate significant differences between the forests in terms of profile totals

roots) in the mineral soil also increased significantly with increasing elevation (Table 5), leading to a significantly higher standing fine root necromass at the two uppermost sites (data not shown).

Fine root morphology also changed along the altitudinal transect: the specific root tip abundance (number of tips per unit dry mass) increased linearly with elevation by a factor of ca. 2 in the organic layer (Table 5). Moreover, a significant increase in specific root tip abundance in the upper mineral soil occurred between the two $P$. pepei stands. Differences in specific fine root area SRA could also be detected among the stands: $P$. lanata fine roots at the lowermost site showed comparatively high SRA values; however, SRA increased significantly from the intermediate $P$. pepei stand towards the treeline site, where the overall maximum values were found. Fine roots of $P$. pepei at the treeline site had significantly smaller diameters compared to the two stands of $P$. pepei and P. lanata below the treeline.

As a result of both, changes in fine root biomass and root morphology, root tip frequency (number of root tips per unit ground area) increased conspicuously from the lowermost to the uppermost stand: there were 18 times more root tips per square metre ground area at the treeline stand compared to the lowermost site, even though the soil was much shallower in the uppermost stand (Fig. 2 b). The fine

Table 4 Structural and chemical leaf traits of the Polylepis trees in the three forests

\begin{tabular}{|c|c|c|c|}
\hline Elevation (m) & 3,650 & 3,800 & 4,050 \\
\hline Single leaf area $\left(\mathrm{cm}^{2}\right)$ & $11.98 \pm 0.46 \mathrm{a}$ & $1.76 \pm 0.06 \mathrm{~b}$ & $1.62 \pm 0.05 b$ \\
\hline Specific leaf area $\left(\mathrm{cm}^{2} \mathrm{~g} \mathrm{dm}^{-1}\right)$ & $66.0 \pm 6.1 \mathrm{a}$ & $112.7 \pm 1.7 \mathrm{~b}$ & $86.0 \pm 3.1 \mathrm{c}$ \\
\hline Nitrogen concentration $\left(\mathrm{mmol} \mathrm{N} \mathrm{g} \mathrm{dm}{ }^{-1}\right)$ & $1.20 \pm 0.08 \mathrm{a}$ & $1.31 \pm 0.02 \mathrm{ab}$ & $1.50 \pm 0.07 \mathrm{~b}$ \\
\hline$\left(\mu \mathrm{mol} \mathrm{N} \mathrm{cm}{ }^{-2}\right)$ & $18.69 \pm 1.52 \mathrm{a}$ & $11.66 \pm 0.18 \mathrm{~b}$ & $17.49 \pm 0.74 \mathrm{a}$ \\
\hline $\begin{array}{l}\text { Phosphorus concentration }\left(\mu \mathrm{mol} \mathrm{P} \mathrm{g} \mathrm{dm}{ }^{-1}\right) \\
\left(\mu \mathrm{mol} \mathrm{P} \mathrm{cm}^{-2}\right)\end{array}$ & $\begin{array}{l}86.7 \pm 6.2 \mathrm{a} \\
1.35 \pm 0.11 \mathrm{a}\end{array}$ & $\begin{array}{l}58.7 \pm 2.8 \mathrm{~b} \\
0.52 \pm 0.02 \mathrm{~b}\end{array}$ & $\begin{array}{l}67.3 \pm 2.9 \mathrm{~b} \\
0.79 \pm 0.04 \mathrm{~b}\end{array}$ \\
\hline$\delta^{13} \mathrm{C}$ signature $(\%)$ & $-26.63 \pm 0.46 \mathrm{a}$ & $-26.91 \pm 0.33 \mathrm{a}$ & $-26.78 \pm 0.27 \mathrm{a}$ \\
\hline
\end{tabular}

Given are means and standard errors. Different Latin letters indicate significant differences among the stands $(P<0.05, n=60$ for single leaf area, and $n=6$ for the other parameters) 
Table 5 Structural, morphological, and chemical traits of the fine root system in the three Polylepis forests

\begin{tabular}{|c|c|c|c|c|}
\hline Elevation (m) & & 3,650 & 3,800 & 4,050 \\
\hline ine root biomass density $\left(\mathrm{g} \mathrm{dm} \mathrm{l}^{-1}\right)$ & $\begin{array}{l}\text { Organic layer } \\
\text { Mineral soil }(0-10 \mathrm{~cm}) \\
\text { Mineral soil }(10-20 \mathrm{~cm})\end{array}$ & $\begin{array}{l}0.22 \pm 0.04 \text { a } \alpha \\
0.21 \pm 0.04 \text { a } \alpha \\
0.12 \pm 0.05 \text { a } \alpha\end{array}$ & $\begin{array}{l}0.90 \pm 0.10 \mathrm{~b} \alpha \\
0.84 \pm 0.14 \mathrm{~b} \alpha \\
0.21 \pm 0.07 \mathrm{a} \beta\end{array}$ & $\begin{array}{l}1.00 \pm 0.13 \mathrm{~b} \alpha \\
3.05 \pm 0.52 \mathrm{c} \beta \\
\quad-\end{array}$ \\
\hline Fine root necromass density $\left(\mathrm{g} \mathrm{dm} \mathrm{l}^{-1}\right)$ & $\begin{array}{l}\text { Organic layer } \\
\text { Mineral soil }(0-10 \mathrm{~cm}) \\
\text { Mineral soil }(10-20 \mathrm{~cm})\end{array}$ & $\begin{array}{l}0.71 \pm 0.23 \text { a } \alpha \\
0.48 \pm 0.04 \text { a } \alpha \\
0.35 \pm 0.08 \text { a } \alpha\end{array}$ & $\begin{array}{l}0.80 \pm 0.14 \mathrm{a} \alpha \\
1.49 \pm 0.39 \mathrm{a} \alpha \beta \\
2.01 \pm 0.50 \mathrm{a} \beta\end{array}$ & $\begin{array}{l}0.71 \pm 0.07 \text { a } \alpha \\
2.16 \pm 0.16 \mathrm{~b} \beta \\
\quad-\end{array}$ \\
\hline Specific fine root surface area $\left(\mathrm{cm}^{2} \mathrm{~g} \mathrm{dm}^{-1}\right)$ & $\begin{array}{l}\text { Organic layer } \\
\text { Mineral soil }(0-10 \mathrm{~cm}) \\
\text { Mineral soil }(10-20 \mathrm{~cm})\end{array}$ & $\begin{array}{l}361 \pm 37 \text { a } \alpha \\
365 \pm 24 \text { a } \alpha \\
365 \pm 40 \text { a } \alpha\end{array}$ & $\begin{array}{l}368 \pm 44 \text { a } \alpha \\
251 \pm 31 \text { b } \beta \\
362 \pm 47 \text { a } \beta\end{array}$ & $\begin{array}{l}584 \pm 83 \text { b } \alpha \\
363 \pm 38 \text { a } \beta \\
\quad-\end{array}$ \\
\hline Fine root area index $\left(\mathrm{m}^{2} \mathrm{~m}^{-2}\right)$ & $\begin{array}{l}\text { Organic layer } \\
\text { Mineral soil }(0-10 \mathrm{~cm}) \\
\text { Mineral soil }(10-20 \mathrm{~cm}) \\
\text { Profile total }\end{array}$ & $\begin{array}{l}0.67 \pm 0.11 \text { a } \alpha \\
0.48 \pm 0.14 \text { a } \alpha \\
0.01 \pm 0.01 \text { a } \beta \\
1.15 \pm 0.20 \text { a }\end{array}$ & $\begin{array}{l}3.30 \pm 0.37 \mathrm{~b} \alpha \\
1.21 \pm 0.26 \mathrm{~b} \beta \\
0.89 \pm 0.40 \mathrm{~b} \chi \\
5.40 \pm 0.78 \mathrm{~b}\end{array}$ & $\begin{array}{l}6.63 \pm 1.26 \mathrm{c} \alpha \\
2.98 \pm 0.90 \mathrm{ab} \beta \\
\quad- \\
9.61 \pm 1.60 \mathrm{c}\end{array}$ \\
\hline Specific root tip abundance (number $\mathrm{mg} \mathrm{dm}^{-1}$ ) & $\begin{array}{l}\text { Organic layer } \\
\text { Mineral soil }(0-10 \mathrm{~cm}) \\
\text { Mineral soil }(10-20 \mathrm{~cm})\end{array}$ & $\begin{aligned} 5.6 & \pm 1.0 \mathrm{a} \alpha \\
7.7 & \pm 1.3 \mathrm{ab} \alpha \\
13.3 & \pm 11.7 \mathrm{a} \alpha\end{aligned}$ & $\begin{aligned} 12.0 & \pm 2.3 \mathrm{~b} \alpha \\
7.0 & \pm 1.8 \text { a } \beta \\
8.0 & \pm 2.0 \text { a } \alpha \beta\end{aligned}$ & $\begin{array}{l}25.5 \pm 5.9 \mathrm{c} \alpha \\
13.2 \pm 2.5 \mathrm{~b} \alpha \\
\quad-\end{array}$ \\
\hline Mean fine root diameter $(\mathrm{mm})$ & $\begin{array}{l}\text { Organic layer } \\
\text { Mineral soil }(0-10 \mathrm{~cm}) \\
\text { Mineral soil }(10-20 \mathrm{~cm})\end{array}$ & $\begin{array}{l}30.7 \pm 1.7 \text { a } \alpha \\
28.2 \pm 1.0 \text { a } \alpha \\
26.3 \pm 3.8 \text { a } \alpha\end{array}$ & $\begin{array}{l}29.2 \pm 1.5 \text { a } \alpha \\
30.9 \pm 2.0 \text { a } \alpha \\
30.2 \pm 4.1 \text { a } \beta\end{array}$ & $\begin{array}{l}21.8 \pm 0.7 \mathrm{~b} \alpha \\
24.1 \pm 1.5 \mathrm{~b} \alpha \\
\quad-\end{array}$ \\
\hline$\delta^{13} \mathrm{C}$ signature $(\%)$ & $\begin{array}{l}\text { Organic layer } \\
\text { Mineral soil }(0-10 \mathrm{~cm}) \\
\text { Profile mean }\end{array}$ & $\begin{array}{l}-26.41 \pm 0.16 \text { a } \alpha \\
-26.19 \pm 0.17 \text { a } \alpha \\
-26.33 \pm 0.12 \mathrm{a}\end{array}$ & $\begin{array}{l}-28.28 \pm 0.09 \mathrm{~b} \alpha \\
-28.03 \pm 0.18 \mathrm{~b} \alpha \\
-28.12 \pm 0.10 \mathrm{~b}\end{array}$ & $\begin{array}{l}-28.47 \pm 0.11 \mathrm{~b} \alpha \\
-28.42 \pm 0.06 \mathrm{~b} \alpha \\
-28.45 \pm 0.07 \mathrm{c}\end{array}$ \\
\hline
\end{tabular}

Given are means and standard errors. Different Latin or Greek letters indicate significant differences among the stands or among horizons, respectively $(P<0.05, n=20$ for fine root density and fine root area index, $n=17-20,12-16$, and 2-7 for specific surface area and specific root tip abundance, and fine root diameter in the organic layer, and the upper and lower mineral soil horizon, and $n=23-40$ for the $\mathrm{C}$ isotopic signature)

root area index RAI (root surface area per unit ground area) increased by a factor of more than 8 from the lowermost to the uppermost stand (Table 5).

In contrast to leaf carbon isotopic signature, $\delta^{13} \mathrm{C}$ value of the fine root material decreased significantly with elevation (i.e. more negative values at higher elevation). Within a stand, fine roots in the organic layer tended to have a more negative $\delta^{13} \mathrm{C}$ value compared to those in the mineral soil (Table 5).

\section{Young growth of the Polylepis stands}

Density of young growth increased with altitude from a maximum of 2 shoots $4 \mathrm{~m}^{-2}$ at the lower elevation to a maximum of 1,972 shoots at the uppermost stand (Fig. 3). Young growth at the two lower sites was not connected to adult trees, and tended to be more common in the grassland. Variance was generally large rendering differences between grasslands and forest not significant for the two lower sites. The pattern reversed at the upper plots where a mean of 1,091 shoots $4 \mathrm{~m}^{-2}$ grew inside the stands, while the mean density in the grasslands was 4 shoots $4 \mathrm{~m}^{-2}$ (Fig. 3). Digging revealed that all shoots inside the upper forest stand were interconnected, and eventually could be traced back to larger roots of adult trees. Thus, $P$. pepei at the uppermost stand was capable of clonal growth by developing root suckers. Shoots in the open grassland also had long roots and may also well have originated from root suckers.

\section{Discussion}

Thermal conditions of the Polylepis forests at the treeline

Several thresholds were proposed for temperatures at the alpine treeline. These include the $10^{\circ} \mathrm{C}$ July air temperature isotherm for the temperate and boreal region (e.g. Köppen 1931 ) or the $3-6^{\circ} \mathrm{C}$ summer (growing season) air temperature isotherm at tropical or subtropical mountains (Körner 1998; Körner 2003). Recent data imply that tree-line positions are more closely associated with soil than with air 
Fig. 3 Number of small shoots $(<2 \mathrm{~cm} \mathrm{dbh})$ inside and outside the Polylepis forests. Given are means \pm 1 SE from four randomly selected subplots $\left(4 \mathrm{~m}^{2}\right)$ per altitude and forest or grassland site. Probability values refer to the analysis of differences between forest and adjacent grassland location
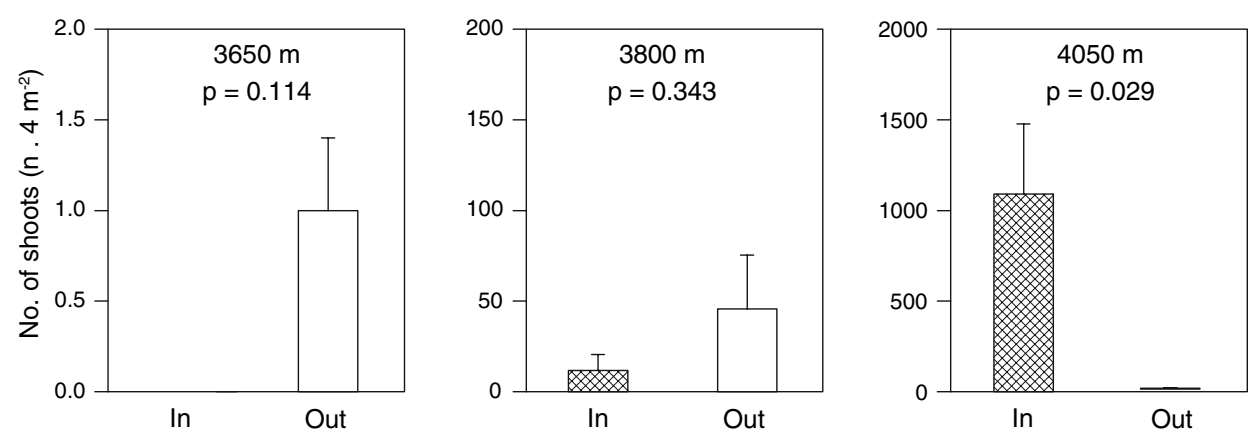

temperatures (e.g. Körner and Hoch 2006). In their global survey Körner and Paulsen (2004) found a coincidence of the treeline position with the $6.7^{\circ} \mathrm{C}$ growing season isotherm in the root zone $(10 \mathrm{~cm}$ soil depth), while mean growing season temperatures in the root zone in the tropical/subtropical mountains were lower at 5 to $6^{\circ} \mathrm{C}$. Accordingly, Hoch and Körner (2005) recorded a mean root zone temperature of $5.4^{\circ} \mathrm{C}$ in the world's highest forests formed by Polylepis tarapacana at the volcano Sajama in the western (dry) cordillera of Bolivia. Our own measurements at the treeline of $P$. pepei in the eastern (moist) cordillera of Bolivia point to lower values $\left(2.0^{\circ} \mathrm{C}\right.$ root zone temperature, $1.7^{\circ} \mathrm{C}$ air temperature), but data were collected during a short-term field campaign only. Relatively low temperatures are also reported by Kessler and Hohnwald (1998) for a very similar treeline site formed by $P$. pepei at 4,050 $\mathrm{m}$ a.s.l. in the eastern (moist) cordillera north of La Paz (Bolivia), where the mean soil temperature in $5 \mathrm{~cm}$ soil depth was also only $2.5^{\circ} \mathrm{C}$. Bendix and Rafiqpoor (2001) also found relatively low mean soil temperature values (at $10 \mathrm{~cm}$ depth) in stands of $P$. incana and $P$. pauta at the treeline in Ecuador. In Bolivia, treelines formed by $P$. tarapacana grew at mean air temperature between 3.4 and $3.7^{\circ} \mathrm{C}$ (Rada et al. 2001; Garcia-Nunez et al. 2004) and values reported for the uppermost stands of P. sericea in Venezuela (Rada et al. 1996) are also at the lower range of temperature values given by Körner (1998) and Körner and Paulsen (2004) for the tropical regions worldwide. These records suggest that treeline stands built by Polylepis trees seem to occur under specifically cold conditions.

Changes in below-ground vs. above-ground carbon sequestration with altitude

The most conspicuous finding in our study was the contrasting gradients in above-ground and below-ground structure of the three Polylepis stands along the elevational transect. Decreasing tree height, stem diameter, and stand basal area together with increasing stem density indicated a clear reduction of carbon allocation to above-ground tree compartments, while the size (biomass) and surface area (RAI) of the fine root system increased markedly towards the treeline.

The change in above-ground structure with elevation is a well known phenomenon. Decreasing $\mathrm{C}$ investment at high altitudes in above-ground tree compartments were traditionally attributed to a reduced carbon gain due to a limitation in photosynthetic activity and/or an imbalance of annual C fixation vs. respiratory losses (data reviewed by Stevens and Fox 1991; Körner 1998; Grace et al. 2002; Körner 2003a). However, several studies on C assimilation failed to give evidence that tree growth at high elevation is limited by carbon gain (e.g. Slatyer 1978; Häsler 1982; Brodersen et al. 2006; see also review by Körner 2003b). Instead, Körner and co-workers emphasized an alternative hypothesis of sink limitation due to reduced biosynthetic activity under cold growth conditions (Hoch et al. 2002; Hoch and Körner 2003; Hoch and Körner 2005; Shi et al. 2006). Specific hypotheses related to tree-stature, on the other hand, holding for damaging effects due to blowing ice, large snow charge, or winter drought are based on data from high elevation forests of the temperate, boreal, and arctic/antarctic regions (Stevens and Fox 1991; Sveinbjörnsson 2000) but cannot explain the altitudinal trends found in tropical mountains.

For Polylepis trees it has been shown, that above-ground growth at high elevations should not be limited by assimilate shortage: measurements by Rada et al. (1996) on $P$. sericea as well as by Rada et al. (2001) and GarciaNunez et al. (2004) on P. tarapacana indicated sufficient carbon gains even at very high altitudes leading to high concentrations of non-structural carbohydrates (NSC) in above-ground plant tissues (Hoch and Körner 2005) and high frost tolerance (Rada et al. 2001). Though some Polylepis species seem to form small trees only or even shrubs (Kessler 1995), there are reports of relatively high above-ground biomass accumulation and productivity of Polylepis stands not far below the expected climatic treeline position (Young 1993; Fehse et al. 2002). Thus, our finding of tall Polylepis trees with large diameters only 
$400 \mathrm{~m}$ below the treeline in E Bolivia are in general agreement with available data, although heights of 30 $32 \mathrm{~m}$ have never, and $\mathrm{dbh}>100 \mathrm{~cm}$ have rarely been described in the literature for Polylepis so far (e.g., Young 1993). Marked altitudinal decreases in tree height of Polylepis stands were reported in a number of studies (Young 1993), and 2-4 $\mathrm{m}$ in height seems to be typical for Polylepis forests at the treeline (Rada et al. 1996, GarciaNunez et al. 2004, Hoch and Körner 2005).

The wealth of reports on elevational changes in aboveground stand structure is in marked contrast to the scarcity of data on changes in the root system. Luo et al. (2005) found a reduction in biomass of roots along an elevational transect in the Himalayas. However, this investigation differs from our approach by the inclusion of root fractions much larger than $2 \mathrm{~mm}$ in diameter and by the tree individual-based sampling procedure. The few other studies on elevational effects on the fine root system, on the other hand, also point to increasing fine root biomass with elevation on the stand area level. Hence, in moist tropical forests in Queensland (Australia) Maycock and Congdon (2000) found a 2.5 times larger fine root biomass average in stands of 600-1,000 $\mathrm{m}$ a.s.l. than in stands between 50 and $120 \mathrm{~m}$ a.s.l. A similar result was found by McGroddy and Silver (2000) for an elevational transect of tropical moist forests in Puerto Rico. However, both studies covered only lower elevation forests. More directly comparable are data from two extended altitudinal transects on forest structure and productivity at Mt. Kinabalu (Malaysia) by Kitayama and Aiba (2002): our re-analysis of that data set revealed a significant linear increase in fine root biomass along the two transects between 650 and 3,080 m a.s.l. $\left(r^{2}=0.74\right)$. The results are similar to findings of Leuschner et al. (2007) for a tropical montane forest in South Ecuador, where fine root biomass increased by a factor of $>4$ from 1,050 to $3,060 \mathrm{~m}$ a.s.l. None of the described transect studies, however, reached up to the climatic treeline. In fact, we know of no study on fine root system of trees at the treeline.

Despite that, it is noteworthy that the absolute amounts in fine root biomass of the Polylepis stands lay far below the values of other high elevation forests. With 40 $230 \mathrm{~g} \mathrm{~m}^{-2}$ fine root biomass was markedly lower than the global average value of ca. $1,000 \mathrm{~g} \mathrm{~m}^{-2}$ given for stands above 2,000 $\mathrm{m}$ a.s.l. in a recent review of the available literature data on fine root biomass values in tropical moist forests (Hertel and Leuschner 2008). Whether these relatively low amounts of fine root biomass are typical for Polylepis forests in the Andes remains open since there are no other comparable data on the root system of Polylepis forests. Nevertheless, the observed increase in fine root biomass and fine root system surface area (RAI) clearly follows the altitudinal trends of the fine root system in tropical moist montane forests (review by Hertel and Leuschner 2008).

What possible reasons might be responsible for this increased carbon investment into the fine root system with elevation towards the treeline? According to general growth economy theory (Givnish 1984) the enlargement of the fine root system should reflect a compensation for water or nutrient deficiency. It was shown that high elevation forests can be exposed to severe drought at least periodically (James et al. 1994; Lloyd and Fastie 2002; Li et al. 2004), and those dry conditions have been reported for Polylepis treeline stands as well (Garcia-Nunez et al. 2004; Morales et al. 2004). However, water limitation is unlikely to be an important factor at our study transect in the humid eastern Andes cordillera. Consequently, we could not detect any significant differences in leaf $\delta^{13} \mathrm{C}$ values among trees from different altitudes.

In fact, soils of tropical moist forests at high elevation are more often water-saturated than dry (Vitousek and Sanford 1986; Kappelle 2004). In these cold environments, this causes low $\mathrm{pH}$ values, oxygen depletion, and low microbial activity (Bruijnzeel and Veneklaas 1998; Silver et al. 1999), leading to a reduction in nutrient availability (Meentemeyer 1977; Vitousek and Sanford 1986). Hence, forest growth at such cold sites may be limited by the supply of nutrients, especially of nitrogen (Vitousek and Sanford 1986; Sveinbjörnsson et al. 1992; Timoney 1995; Tanner et al. 1998). Accordingly, the increase in the size of the fine root system towards the treeline might represent an adaptation to lowered nutrient availability.

Although our soil chemical analyses suggest a decrease in nutrient availability with elevation, the analyses of leaf $\mathrm{N}$ and $\mathrm{P}$ contents in our study do not seem to support the idea that the Polylepis trees at the treeline did experience severe nutrient deficiency. We found a moderate decrease in leaf $\mathrm{P}$ concentration, but a slight increase in $\mathrm{N}$ content (expressed on a dry weight basis) from the lowermost to the uppermost stand. This is in contrast to the finding of a weak decrease in leaf $\mathrm{N}$ content with elevation along an elevational transect in Tibet with relatively low $\mathrm{N}$ values $(1.2 \% \mathrm{dm})$ at the treeline (Shi et al. 2006), or an even strong reduction in leaf $\mathrm{N}$ concentration (from 2.1 to $1.1 \%$ $\mathrm{dm})$ with elevation in South Ecuadorian mountain forests (Schuldt, unpublished data). De Lillis et al. (2004), on the other hand, found an increase in leaf $\mathrm{N}$ content (from 1.4 to $2.1 \% \mathrm{dm}$ ) with elevation towards the treeline similar to our results. It has been stated, that high concentrations in leaf photochemical compounds might be a physiological adaptation to low temperatures (Velez et al. 1998), and thus high leaf $\mathrm{N}$ contents may be a consequence of physiological adaptation to cold growth conditions rather than reflecting possible nutrient limitation in the soil (Weih and Karlsson 2001). However, the $\mathrm{N}$ values in our study can be 
judged as much lower than $\mathrm{N}$ contents of $3.0-3.5 \%$ found in Polylepis quadrijuga trees at a lower elevation of ca. 3,200 m a.s.l. in Colombia (Velez et al. 1998). Hence, it remains unclear if the $\mathrm{N}$ and $\mathrm{P}$ leaf contents may allow for identification of possible nutrient shortage in the case of our study.

Another possible explanation for the conspicuous shift in carbon allocation towards the root system with elevation could be found in a hypothesis given by Stevens and Fox (1991). These authors state that under cold growth conditions the long-distance transport of water and nutrients in trees requires a disproportional large carbon investment in the root system compared to warmer environments. Constraints in water and related nutrient uptake from soil to root and across root cells at low temperatures may have purely physical reasons (Stevens and Fox 1991; Sveinbjörnsson 2000). This line of thought would explain the obvious enlargement of the fine root system with elevation of the Polylepis stands towards the treeline, and also the marked decrease in shoot:root ratio illustrated by the sharp decrease in tree height and basal area. Indeed, Karlsson and Nordell (1996) and Weih and Karlsson (2001) demonstrated that $\mathrm{N}$ uptake of birch seedlings under cold conditions might not only be affected by low nutrient availability, but also by reduced nutrient supply due to the physiological inability of root nutrient uptake. Thus, the observed changes in the shoot:root ratio in Polylepis forests with elevation seem to follow the general trend described by Hertel and Leuschner (2008) of marked increase in carbon investment to the root system of tropical moist forests at high altitudes to serve for sufficient nutrient supply.

Elevational changes in leaf and root morphology

Our altitudinal transect study revealed not only marked changes in carbon sequestration but also significant differences in leaf and root morphology between the Polylepis trees of different elevation. Much of these adaptations in leaf morphology to high-altitude climatic conditions are well-known: leaves at higher elevations are smaller and have lower specific leaf area (SLA) values (e.g. Cordell et al. 1998; Aiba and Kitayama 1999; Li et al. 2004). These traits are interpreted as adaptations to harsh conditions at high altitudes such as increasing wind speed, low temperatures, low nutrient availability, high UV-B radiation, and, locally, high vapor pressure deficits (e.g., Box 1981; Chabot and Hicks 1982; Givnish 1987; Reich et al. 1992; Richards 1996). Not all these factors are likely to operate in the forests described here. Dry growth conditions at the treeline in the central cordillera in Bolivia at volcano Sajama are related to very low SLA values of ca. $30 \mathrm{~cm}^{2} \mathrm{~g}^{-1}$ of Polylepis tarapacana (Hoch and Körner 2005), while the SLAs of our Polylepis trees growing in the humid, eastern cordillera region ranged between 66 and $113 \mathrm{~cm}^{2}$ $\mathrm{g}^{-1}$. Moreover, differences between the leaf morphology data in our elevational transect are most likely biased by the presence of two different tree species. However, leaf morphology of the two upper $P$. pepei stands clearly follows the general tendency described above with lower leaf area and significantly lower SLA at the treeline site.

Fine root morphology, on the other hand, showed the opposite trend: specific surface area was highest while fine root diameter was smallest at the treeline, and specific root tip abundance increased markedly with elevation. Thus, not only increasing values of fine root biomass and fine root density but also the increase in root surface area (SRA) and root tip abundance highlights the enlargement of the absorbing parts of the fine root system towards the treeline. Like the changes in fine root biomass, the increase in SRA values and specific root tip abundance likely represents an adaptation to either decreasing nutrient availability from the soil or a physiological constraint in nutrient uptake due to low temperature conditions. Comparable data from high elevation forests in the tropics are missing, but studies on fine root morphology in temperate forests suggest that increased root surface area and root tip number result in increased nutrient uptake per unit root mass. Hence, Pregitzer et al. (1998) showed that root metabolic activity (here: respiration) was higher in fine rootlets $(<0.5 \mathrm{~mm}$ in diameter) compared to roots of larger diameter. Pregitzer et al. (2002) and Guo et al. (2004) emphasize the meaning of small-diameter roots of different North American tree species for nutrient uptake. Small roots, on the other hand, were found to be more susceptible to root mortality under cold growth conditions (Wells and Eissenstatt 2001). Thus, an increase in size of the absorbing organs of the fine root system may also represent a compensation for a lower degree in mycorrhizal infection at the high elevation due to higher root mortality (Sveinbjörnsson 2000). We conclude, that the observed changes in fine root morphology of the Polylepis trees towards the treeline can be seen as an economic mechanism to save carbon costs of the increasing size of the fine root system with elevation. This is especially true comparing the two uppermost $P$. pepei stands: the observed increase in fine root area index (RAI) and root tip frequency (numbers $\mathrm{m}^{-2}$ ) of the stands was higher by far (factor $>2$ ) than the concurrent moderate increase in fine root biomass (factor $<0.3$ ).

Regeneration under different microclimate conditions

Regeneration pattern of the studied Polylepis trees changed markedly along the elevational transect in three ways: (1) 
number of young growth increased with elevation, (2) seedlings were mainly found in the grassland at the lower stands, while young shoots were almost exclusively restricted to the forest interior at the uppermost forest, and (3) young plants at the two lowermost sites were actually seedlings while young growth at the uppermost site were exclusively comprised of root suckers.

Several authors describe constraints in reproduction under the harsh microclimatic conditions at the treeline. Seed rain density and seed quality may decrease with elevation leading to a decrease in seedling establishment at the treeline (Sveinbjörnsson 2000). The occurrence of strong winds as well as frost or summer drought effects hamper growth of seedling (Daniels and Veblen 2003; Piper et al. 2006; Resler 2006). Apparently, differences in microclimatic conditions in- and outside the forest stands are of pivotal importance: in a study on Nothofagus pumilio in South Argentina Cuevas (2000) found that seedling emergence at the treeline was much lower in the open grassland compared to the forest interior. This was attributed to differences in seed rain, but also to constraints in seedling survival under open conditions. Seeding experiments on Polylepis forests at the treeline in Ecuador showed that microclimatic conditions hamper seedling emergence in open grassland at the treeline compared to the forest edge or its interior (Cierjacks et al. 2007). This was related to the special microclimatic conditions near the soil surface: like in our study, mean air and soil temperatures near the ground were slightly cooler inside the uppermost forest, while air temperature in the grassland outside the treeline forest showed markedly higher maximum and lower minimum temperatures compared to the forest conditions. Similar results were found by Wang et al. (2006) for Picea schrenkiana growing at the treeline at Tianshan, China, where seedling recruitment was favoured at sites with relatively high monthly minimum temperatures compared to sites with colder minima. Additionally, vapor pressure deficits (VPD) at our treeline site in Bolivia reached also much more extreme values (by a factor of 3 ) in the grassland than inside the treeline forest ( $20 \mathrm{~cm}$ above the ground), and drought stress has also been reported to affect tree seedlings' vitality (Camarero and Gutierrez 2004; Cuevas 2003; Daniels and Veblen 2004). Thus, there is evidence that extreme events rather than mean values may be important for tree regeneration, which corresponds to the observations on Polylepis in our study.

Climatic conditions at the treeline also influence the adult tree and may affect fruit production and/or trigger a shift to clonal growth. The observed change in recruitment strategies towards clonal growth is in line with a range of studies from harsh environments including treeline ecotones (Holtmeier 2003). Polylepis spec. at the treeline in
Ecuador showed altitudinal trends in reproductive activity and flower and fruit production dropped to zero at the current treeline (Cierjacks et al. 2008). However, the decisive bottlenecks in recruitment may occur at other stages such as the transition from seedling to sapling stage rather than the establishment of seedlings (Stevens and Fox 1991; Sveinbjörnsson 2000; Hoch and Körner 2005). Thus, a range of factors can influence recruitment in a broad sense and it remains open whether the observed patterns in Polylepis regeneration indicate a specific mechanism of treeline formation or just a general response to harsh conditions.

\section{Conclusions}

Our study of high-Andean Polylepis forests in Bolivia reveals elevational changes of various ecological parameters. While some of these findings cannot be clearly rated in their importance for the formation of the Polylepis treeline (e.g., the alteration of the regeneration pattern), the contrasting changes in above- versus below-ground attributes are likely to reflect systematic responses of Polylepis trees to deterioration in both thermal conditions and nutrient supply near the treeline. We conclude therefore that the marked shift in carbon allocation towards the fine root system as well as the significant enlargement of the surface of the fine root system (in terms of a higher surface area and a larger number of root tips) via changes in fine root morphology represent crucial adaptations of Polylepis trees to the harsh environmental conditions at the treeline.

Acknowledgments This study was funded by the German Research Foundation (DFG, project He 3582/1-1). We gratefully acknowledge the invaluable help of Jaime Hamel, Chochabamba, Bolivia, during the field investigations in Bolivia as well as Mechthild Stange for her skilful support of the fine root analyses. We thank Prof. Dr. Michael Kessler for his constructive comments on our manuscript.

Open Access This article is distributed under the terms of the Creative Commons Attribution Noncommercial License which permits any noncommercial use, distribution, and reproduction in any medium, provided the original author(s) and source are credited.

\section{References}

Aiba S-I, Kitayama K (1999) Structure, composition and species diversity in an altitude-substrate matrix of rain forest tree communities on Mount Kinabalu, Borneo. Plant Ecol 140:139157

Bauhus J, Bartsch N (1996) Fine-root growth in beech (Fagus sylvatica) forest gaps. Can J For Res 26:2153-2159

Bendix J, Rafiqpoor MD (2001) Studies on the thermal conditions of soils at the upper tree line in the paramo of Papallacta (eastern cordillera of Ecuador). Erdkunde 55:257-276 
Box EO (1981) Prediciting vegetation types with climate variables. Vegetatio 45:127-139

Brodersen CR, Germino MJ, Smith WK (2006) Photosynthesis during an episodic drought in Abies lasiocarpa and Picea engelmannii across an alpine treeline. Arct Antarct Alp Res 38:34-41

Bruijnzeel LA, Veneklaas EJ (1998) Climatic conditions and tropical montane forest productivity: the fog has not lifted yet. Ecology 79:3-9

Camarero JJ, Gutierrez JR (2004) Pace and pattern of recent treeline dynamics: response of ecotones to climatic variability in the Spanish pyrenees. Clim Change 63:181-200

Chabot BF, Hicks DJ (1982) The ecology of leaf life spans. Ann Rev Ecol Syst 13:229-259

Cierjacks A, Wesche K, Hensen I (2007) Impact of sowing, canopy cover and litter on seedling dynamics of Polylepis species at upper treelines in Central Ecuador. J Trop Ecol 23:309-318

Cierjacks A, Rühr NK, Wesche K, Hensen I (2008) Effects of altitude and livestock on the regeneration of two tree line forming Polylepis species in Ecuador. Plant Ecol (in press)

Cordell S, Goldstein G, Mueller-Dombois D, Vitousek PM (1998) Physiological and morphological variation in Metrosideros polymorphy, a dominant Hawaiian tree species, along an altitudinal gradient: the role of phenotypic plasticity. Oecologia 113:188-196

Cuevas JG (2000) Tree recruitment at the Nothofagus pumilio alpine timberline in Tierra del Fuego, Chile. J Ecol 88:840-855

Cuevas JG (2003) Gap characteristics in relation to forest structure and implications for southern beech forest dynamics. Can J For Res 33:1915-1922

Daniels LD, Veblen TT (2003) Altitudinal treelines of the southern Andes near $40^{\circ} \mathrm{S}$. For Chron 79:237-241

Daniels LD, Veblen TT (2004) Spatiotemporal influences of climate on altitudinal treeline in northern Patagonia. Ecology 85:1284-1296

De Lillis M, Matteuccim G, Valentini R (2004) Carbon assimilation, nitrogen, and photochemical efficiency of different Himalayan tree species along an altitudinal gradient. Photosynthetica 42:597-605

Ellenberg H (1979) Man's influence on tropical mountain ecosystems in South America. J Ecol 67:401-416

Fehse J, Hofstede R, Aguirre N, Paladines C, Kooijman A, Sevink J (2002) High altitude tropical forests: a competitive carbon sink? For Ecol Manage 163:9-25

Garcia-Nunez C, Rada F, Boero C, Gonzalez J, Gallardo M, Azocar A, Libermann-Cruz M, Hilal M, Prado F (2004) Leaf gas exchange and water relations in Polylepis tarapacana at extreme altitudes in the Bolivian Andes. Photosynthetica 42:133-138

Givnish TJ (1984) On the economy of plant form and function. Cambridge University Press, Cambridge

Givnish TJ (1987) Comparative-studies of leaf form-assessing the relative roles of selective pressures and phylogenetic constraints. New Phytol 106:131-160

Goldstein G, Meinzer FC, Rada F (1994) Environmental biology of a tropical treeline species, Polylepis sericea. In: Rundel PW, Smith AP, Meinzer FC (eds) Tropical alpine environments: plant form and function. Cambridge University Press, Cambridge, pp 129-149

Grace J, Berninger F, Nagy L (2002) Impacts of climate change on the tree line. Ann Bot Lond 90:537-544

Guo DL, Mitchell RJ, Hendricks JJ (2004) Fine root branch orders respond differentially to carbon source-sink manipulations in a longleaf pine forest. Oecologia 140:450-457

Häsler R (1982) Net photosynthesis and transpiration of Pinus montana on east and north facing slopes at alpine timberline. Oecologia 54:14-22

Hensen I (2002) Impacts of anthropogenic activity on the vegetation of Polylepis woodland in the region of Cochabamba/Bolivia. Ecotropica 8:183-203
Hertel D (1999) Das Feinwurzelsystem von Rein- und Mischbeständen der Rotbuche: Struktur, Dynamik und interspezifische Konkurrenz. Dissertationes Botanicae 317. Gebrüder Borntraeger, Stuttgart, Germany

Hertel D, Leuschner C (2002) A comparison of four different fine root production estimates with ecosystem carbon balance data in a Fagus-Quercus mixed forest. Plant Soil 239:237-251

Hertel D, Leuschner C (2008) Fine root mass and fine root production in tropical moist forests as dependent on soil, climate and elevation. In: Bruijnzeel LA, Juvik J (eds) Mountains in the mist: science for conserving and managing tropical montane cloud forests. University of Hawai'i Press, Honolulu (in press)

Hijmans RJ, Cameron SE, Parra JL, Jones PG, Jarvis A (2005) Very high resolution interpolated climate surfaces for global land areas. Int J Climatol 25:1965-1978

Hoch G, Popp M, Körner C (2002) Altitudinal increase of mobile carbon pools in Pinus cembra suggest sink limitation of growth at the Swiss treeline. Oikos 98:361-374

Hoch G, Körner C (2003) The carbon charging of pines at the climatic treeline: a global comparison. Oecologia 135:10-21

Hoch G, Körner C (2005) Growth, demography and carbon relations of Polylepis trees at the world's highest treeline. Funct Ecol 19:941-951

Holtmeier FK (2003) Mountain timberlines: ecology, patchiness, and dynamics. Advances in global change research, vol 14. Kluwer, Dordrecht

James JC, Grace J, Hoad SP (1994) Growth and photosynthesis of Pinus sylvestris at its altitudinal limit in Scotland. J Ecol 82:297306

Kappelle M (2004) Tropical forests: tropical montane forests. In: Burley J, Evans J, Youngquist JA (eds) Encyclopedia of forest sciences, vol 4, Elsevier, Oxford, pp 1782-1793

Karlsson PS, Nordell KO (1996) Effects of soil temperature on nitrogen economy and growth of mountain birch near its presumed low temperature distribution limit. Ecoscience 3:183-189

Kessler M (1995) Polylepis-Wälder Boliviens: Taxa, Ökologie, Verbreitung und Geschichte. Dissertationes Botanicae 246. Gebrüder Borntraeger, Stuttgart, Germany

Kessler M, Hohnwald S (1998) Bodentemperaturen innerhalb und außerhalb bewaldeter und unbewaldeter Blockhalden in den bolivianischen Hochanden. Erdkunde 52:54-62

Kessler M, Schmidt-Lebuhn AN (2005) Taxonomical and distributional notes on Polylepis (Rosaceae). Org Divers Evol 5:1-10

Kitayama K, Aiba S-I (2002) Ecosystem structure and productivity of tropical rain forests along altitudinal gradients with contrasting soil phosphorus pools on Mount Kinabalu, Borneo. J Ecol 90:37-51

Köppen W (1931) Grundriss der Klimakunde. De Gruyer, Berlin

Körner C (1998) A re-assessment of high elevation treeline positions and their explanation. Oecologia 115:445-459

Körner C (2003a) Alpine plant life: functional plant ecology of high mountain ecosystems. Springer, Berlin

Körner C (2003b) Carbon limitation in trees. J Ecol 91:4-17

Körner C, Paulsen J (2004) A world-wide study of high altitude treeline temperatures. J Biogeogr 31:713-732

Körner C, Hoch G (2006) A test of treeline theory on a montane permafrost island. Arct Antarct Alp Res 38:113-119

Leuschner C, Moser G, Bertsch C, Röderstein M, Hertel D (2007) Large altitudinal increase in tree root/shoot ratio in tropical mountain forests of Ecuador. Bas Appl Ecol 8:219-230

Li C, Liu S, Berninger F (2004) Picea seedlings show apparent acclimation to drought with increasing altitude in the eastern Himalaya. Trees 18:277-283

Lloyd AH, Fastie CL (2002) Spatial and temporal variability in the growth of treeline trees in Alaska. Clim Change 52:481-509 
Luo T, Brown S, Pan Y, Shi P, Ouyang H, Yu Z, Zhu H (2005) Root biomass along subtropical to alpine gradients: global implication from Tibetan transect studies. For Ecol Manage 206:349-363

Maycock CR, Congdon RA (2000) Fine root biomass and soil N and $\mathrm{P}$ in north Queensland rain forests. Biotropica 32:185-190

McGroddy M, Silver WL (2000) Variations in belowground carbon storage and soil $\mathrm{CO}_{2}$ flux rates along a wet tropical climate gradient. Biotropica 32:614-624

Meentemeyer V (1977) Climatic regulation of decomposition rates of organic matter in terrestrial ecosystems. In: Adrians DC, Brisbin IL (eds) Environmental chemistry and cycling processes. United States Dep. Energy Symp. Series CONF-760429, Washington DC, USA, pp 779-789

Morales M, Villalba R, Grau R, Paolini L (2004) Rainfall-controlled tree growth in high-elevation subtropical treelines. Ecology 85:3080-3089

Ohsawa M (1990) An interpretation of latitudinal patterns of forest limits in south and east-Asian mountains. J Ecol 78:326-339

Persson H (1978) Root dynamics in a young Scots pine stand in Central Sweden. Oikos 30:508-519

Piper FI, Cavieres LA, Reyes-Diaz M, Corcuera LJ (2006) Carbon sink limitation and frost tolerance control performance of the tree Kageneckia angustifolia D. Don (Rosaceae) at the treeline in central Chile. Plant Ecol 185:29-39

Pregitzer KS, Laskowski MJ, Burton AJ, Lassard VC, Zak DR (1998) Variation in sugar maple root respiration with root diameter and soil depth. Tree Physiol 18:665-670

Pregitzer KS, DeForest JL, Burton AJ, Allen MF, Ruess RW, Hendrick RL (2002) Fine root architecture of nine North American trees. Ecol Monogr 72:293-309

Rada F, Azocar A, Briceno B, Gonzalez J, Garcia-Nunez C (1996) Carbon and water balance in Polylepis sericea, a tropical treeline species. Trees 10:218-222

Rada F, Garcia-Nunez C, Boero C, Gallardo M, Hilal M, Gonzalez J, Prado F, Libermann-Cruz M, Azocar A (2001) Low-temperature resistance in Polylepis tarapacana, a tree growing at the highest altitudes in the world. Plant Cell Environ 24:377-381

Reich PB, Walters MB, Ellsworth DS (1992) Leaf life-span in relation to leaf, plant, and stand characteristics among diverse ecosystems. Ecol Monogr 62:365-392

Renison D, Hensen I, Cingolani AM (2004) Anthropogenic soil degradation affects seed viability in Polylepis australis mountain forests of central Argentina. For Ecol Manage 196:327-333

Resler LM (2006) Geomorphic controls of spatial pattern and process at alpine treeline. Prof Geogr 58:124-138

Richards PW (1996) The tropical rain forest. Cambridge University Press, Cambridge

Rundel PW, Gibson AC, Midgley GS, Wand SJE, Palma B, Kleier C, Lambrinos J (2003) Ecological and ecophysiological patterns in a pre-altiplano shrubland of the Andean Cordillera in northern Chile. Plant Ecol 169:179-193
Shi PL, Körner C, Hoch G (2006) End of season carbon supply status of woody species near the treeline in western China. Bas Appl Ecol 7:370-377

Silver WL, Keller M, Lugo AE (1999) Soil oxygen availability and biogeochemical cycling along elevation and topographic gradients in Puerto Rico. Biogeochem 44:301-328

Simpson BB (1986) Speciation and specialization of Polylepis in the Andes. In: Vuillemier F, Monasterio M (eds) High altitude tropical biogeography. Oxford University Press, New York, pp 304-316

Slatyer RO (1978) Altitudinal variation in photosynthetic characteristics of snow gum, Eucalyptus pauciflora Sieb. ex Spreng. Relationship between gradients of field temperature and photosynthetic temperature optima in snowy mountains area. Aust J Bot 26:111-121

Stevens GC, Fox JF (1991) The causes of treeline. Ann Rev Ecol Syst 22:177-191

Sveinbjörnsson B (2000) North American and European treelines: external forces and internal processes controlling position. Ambio 29:388-395

Sveinbjörnsson B, Nordell O, Kauhanen H (1992) Nutrient relations of mountain birch growth at and below the elevational tree-line in Swedish Lapland. Funct Ecol 6:213-220

Tanner EVJ, Vitousek PM, Cuevas E (1998) Experimental investigation of nutrient limitation of forest growth on wet tropical mountains. Ecology 79:10-22

Timoney K (1995) Tree and tundra cover anomalies in the subarctic forest tundra of northwest Canada. Arctic 48:13-21

Tranquillini W (1979) Physiological ecology of the alpine timberline. Tree existence at high altitudes with special reference to the European Alps. Ecological Studies, vol 31. Springer, Berlin

Van Praag HJ, Sougnez-Remy S, Weissen F, Carletti G (1988) Root tunover in a beech stand of the Belgian Ardennes. Plant Soil 105:87-103

Velez V, Cavelier J, Devia B (1998) Ecological traits of the tropical treeline species Polylepis quadrijuga (Rosaceae) in the Andes of Colombia. J Trop Ecol 14:771-787

Vitousek PM, Sanford RL (1986) Nutrient cycling in moist tropical forest. Ann Rev Ecol Syst 17:137-167

Wang T, Zhang Q-B, Ma K (2006) Treeline dynamics in relation to climatic variability in the central Tianshan Mountains, northwestern China. Global Ecol Biogeogr 15:406-415

Wardle P (1981) Is the alpine timberline set by physiological tolerance, reproductive capacity, or biological interactions? Proc Ecol Soc Aust 11:53-66

Weih M, Karlsson PS (2001) Growth response of Mountain birch to air and soil temperature: is increasing leaf-nitrogen content an acclimation to lower air temperature? New Phytol 150:147-155

Wells CE, Eissenstat DM (2001) Marked differences in survivorship among apple roots of different diameters. Ecology 82:882-892

Young KR (1993) Tropical timberlines: changes in forest structure and regeneration between two Peruvian timberline margins. Arct Antarct Alp Res 25:167-174 